\title{
KESADARAN BERORGANISASI DALAM BUKU TEKS PELAJARAN SEJARAH SMA
}

\author{
Moch Wildan Ramadan \\ SMA Santo Aloysius 2 Bandung \\ mochwildanramadan92@gmail.com
}

\begin{abstract}
Textbooks are one of the most important learning resources in learning process. This article analyzes the discourse of organizational awareness in textbooks on the history subject in Senior High School. The method used in this research is critical discourse analysis developed by Van Dijk. The result of the study is done through several elements of Van Dijk's critical discourse: thematic, schematic, semantic, syntactic, stylistic, and rhetorical. The focus of analysis is the organizational awareness during the movement era which is considered to be highly relevant to today's generation to forge themselves and discover their national identity as the future generation.
\end{abstract}

Abstrak: $\quad$ Buku teks pelajaran merupakan salah satu sumber belajar terpenting dalam proses pembelajaran. Artikel ini menganalisis wacana kesadaran berorganisasi dalam buku teks pelajaran sejarah Sekolah Menengah Atas (SMA). Metode penelitian yang digunakan dalam penelitian ini adalah analisis wacana kritis yang dikembangkan oleh Van Dijk. Adapun hasil penetian yang dikembangkan ditinjau melalui beberapa elemen dalam wacana kritis Van Dijk antara lain melalui tematik, skematik, semantik, sintaksis, stilistik, dan retoris. Fokus analisis terkait kesadaran berorganisasi pada masa pergerakan dinilai sangat relevan untuk generasi muda saat ini untuk menempa diri dan menemukan identitas nasional mereka sebagai generasi penerus.

Kata Kunci: $\quad$ kesadaran berorganisasi, masa Pergerakan Nasional, buku teks sejarah

\section{PENDAHULUAN}

Menanamkan semangat dan kesadaran berorganisasi sejak dini adalah merupakan hal yang penting karena pengalaman dalam berorganisasi akan mengajarkan angotanya untuk melihat realitas kehidupan di lingkungannya secara kritis, menumbuhkan jiwa kritis, cerdas, kreatif, serta menanamkan semangat persatuan dan kesatuan. Hal tersebut bisa kita lihat pada masa perjuangan kemerdekaan di masa pergerakan setelah tahun 1908. Masa itu telah melahirkan cendikiawancendikiawan kritis yang menjadi motor penggerak melawan kolonialisme melalui organisasi-organisasi pergerakan.

Semangat pergerakan harus selalu tersampaikan kepada generasi muda agar jiwa persatuan dan kesatuan terus mengalir dalam diri mereka. mencegah berubahnya generasi kita menjadi generasi yang individulis dan apatis. Penyampaian semangat perjuangan melalui organisasi bisa kita sampaikan melalui pelajaran sejarah, baik itu di tingkat SMP maupun SMA/MA. Dengan menanamkan nilai-nilai sejarah, maka keteladanan dapat senantiasa disampaikan kepada generasi penerus bangsa.

Salah satu media pembelajaran sejarah yang bisa digunakan dalam menanamkan nilai-nilai di dalamnya adalah melalui buku teks pelajaran sejarah. Perlu diketahui, buku teks atau buku pelajaran adalah buku yang disusun oleh para ahli untuk menunjang proses pembelajaran. Buku teks merupakan buku yang berisi ilmu pengetahuan hasil analisis terhadap kurikulum dalam bentuk tertulis. Buku teks merupakan salah satu sarana untuk menunjang proses kegiatan belajar mengajar. Tentu saja dalam pelajaran sejarah pun terdapat beragam variasi mengenai penulisan buku teks.

Kesadaran untuk menulis buku pembelajaran sejarah sudah ada sejak awal kemerdekaan. Pada awal kemerdekaan terbit buku-buku teks pelajaran sejarah, baik yang diterbitkan oleh individuindividu maupun resmi dari pemerintah melalui Kementerian Pendidikan dan Kebudayaan pada saat itu. Akan tetapi yang terjadi adalah ketidak sesuaian antara kebutauhan melalui pendekatan penulisan sejarahnya. Karena sejatinya dalam penulisan sejarah dipengaruhi oleh jiwa jamannya. Dan Indonesia baru saja terlepas dari belenggu penjajahan (Ali, dalam Darmawan, $2010: 1$ ).

Buku-buku teks pelajaran sejarah tersebut ternyata kurang sesuai dengan kebutuhan Indonesia yang baru saja merdeka. Pendekatan lama dalam penulisan sejarah sudah kurang sesuai dengan kondisi Indonesia yang sudah merdeka karena

HISTORIA: Jurnal Pendidik dan Peneliti Sejarah, p-issn:2620-4789 | e-issn:2615-7993 
kebanyakan buku-buku pelajaran tersebut lebih banyak merujuk pada buku sejarah karya Dr. F.W. Stapel yang masih bersifat Nederlandosentris. Pendekatan baru mengenai penulisan sejarah nasional yang dibutuhkan dalam pendidikan sejarah di sekolah-sekolah adalah yang melihat sejarah dari perspektif Indonesia dan yang dapat membentuk kepribadian bangsa. Hal ini disebut dengan buku yang bersifat Indonesiasentris.

Sebagai upaya untuk mengimplementasikan gagasan tersebut, maka diselenggarakan Seminar Sejarah Indonesia Pertama di Yogyakarta pada tahun 1957. Dalam seminar itu di samping bertujuan untuk memperdalam pemikiran tentang sejarah Indonesia sebagai sejarah nasional, diperbincangkan pula keperluan mendesak yaitu penulisan buku-buku pelajaran sejarah. Kemudian seminar sejarah tersebut berlanjut di Yogyakarta hingga pada tahun 1970. Dari seminar itu berhasil menyusun buku standar Sejarah Nasional Indonesia (SNI) sebanyak enam jilid. Buku ini sering pula disebut dengan buku 'babon' yang menjadi sumber rujukan utama pada saat itu (Darmawan, 2010: 1).

Pelajaransejarahmerupakan matapelajaranyang tujuannya memiliki kaitan dengan pembentukan watak bangsa. Tujuan tersebut membuat tujuan pelajaran sejarah akan berkaitan dengan ideologi politik kenegaraan. Negara memiliki kewajiban membentuk watak kebangsaan yang dilakukan melalui pendidikan, salah satunya dengan mata pelajaran sejarah, yaitu melalui buku teks sejarah. Kewajiban negara tersebut diimplementasikan melalui kebijakan pendidikan kurikulum. Buku teks pelajaran pada hakikatnya merupakan penjabaran isi kurikulum secara operasional (Sitepu, 2012: 27). Dengan demikian tujuan pembelajaran sejarah menjadi ideologis untuk membentuk kepribadian dan watak bangsa, termasuk memperkuat identitas nasional di dalamnya.

Akan tetapi sebagaimana yang dijelaskan tadi dari tujuan penulisan buku teks sejarah sebagai pencetak generasi penerus bangsa sesuai dengan watak bangsa. Penulisan buku sejarah ini harus sesuai pula sebagai sumber ilmiah yang bersifat saintifisme. Buku teks pelajaran sejarah merupakan salah satu karya historiografi yang diperuntukan bagi kepentingan pendidikan. Kegunaan praktis bagi pendidikan, tidaklah berarti melepaskan diri dari penggunaan kaidah-kaidah akademik historiografi dalam ilmu sejarah. Syarat-syarat keilmiahan harus tetap diperhatikan. Beberapa persyaratan keilmiahan misalnya sumber fakta yang digunakan, kebenaran fakta, pendekatan penafsiran terhadap fakta, aspek keruangan, aspek waktu, dan lainlain. Secara idealnya antara misi pendidikan dan penggunaan kaidah keilmuan dalam historiografi buku teks pelajaran sejarah menjadi lengkap.

Seperti yang telah dikemukakan sebelumnya bahwa pembelajaran sejarah harus membentuk keperibadian bangsa dengan insan akademik yang cerdas, maka penulis merasa penting mengkaji munculnya kesadaran untuk berorganisasi sebagaimana yang terjadi pada insan generasi pergerakan. Di mana dengan adanya pendidikan serta mengimplementasikannya dalam wadah organisasi, maka kualitas generasi tersebut akan semakin tertempa baik dari segi keilmuan/ pengetahuan karena akan dihadapkan pada berbagai pengalaman baru dalam berorganisasi. Sekaligus, organisasi sebagai wadah untuk menempa rasa persatuan di dalamnya.

Penulis menganggap bahwa organisasi merupakan cikal bakal lahirnya persatuan nasional, cikal bakal lahirnya kesadaran kebangsaan. Organisasi menjadi awal mulanya para generasi di masa pergerakan menemukan identitas bangsa mereka dengan dipertemukan bersama generasi terdidik lainnya dari berbagai daerah di Nusantara sebelum adanya konsep Bangsa Indonesia. Golongan terdidik ini lambat laun menyadari realitas kehidupan terjajah mereka di negeri sendiri. Terjajah di tanah airnya sendiri oleh bangsa asing. Kemudian membangun persaudaraan melalui organisasi, karena merasa memiliki persamaan nasib sepenanggungan. Sehingga seluruh generasi muda tersebut bersatu dan berhasil melepaskan bangsanya dari belenggu penjajahan bangsa asing.

Dengan demikian penulis akan mengkaji bagaimana materi dalam buku teks yang saat ini digunakan menyampaikan kesadaran untuk berorganisasinya kepada peserta didik dalam kurikulum 2013. Buku yang akan dikaji adalah buku sejarah Indonesia (wajib) kelas XI karya Ratna Hapsari terbitan Erlangga, dengan pokok bahasan materi organisasi pergerakan nasional: sarana perjuangan melawan kolonialisme di Indonesia.

HISTORIA: Jurnal Pendidik dan Peneliti Sejarah, p-issn:2620-4789 | e-issn:2615-7993 


\section{METODE}

Penelitian ini dilakukan dengan menggunakan metode penelitian kualitatif berupa metode analisis wacana kritis. Metode kualitatif adalah prosedur penelitian yang menghasilkan data deskriptif, yaitu ucapan atau tulisan, atau perilaku yang dapat diamati dari subjek itu sendiri (Fuchran, 1998: 11). Sementara itu, metode penelitian analisis wacana kritis merupakan salah satu contoh penerapan dari metode kualitatif yang dilakukan secara eksplanatif. Dengan menggunakan metode analisis wacana kritis ini, analisis akan difokuskan pada aspek kebahasaan dan konteks-konteks yang terkait dengan aspek tersebut.

Konteks di sini dapat berarti bahwa aspek kebahasaan tersebut digunakan untuk tujuan dan praktik tertentu. Analisis wacana berita dalam penelitian ini dilakukan dengan cara menginterpretasi atau menafsirkan teks-teks yang ada. Oleh karena itu, subjektivitas tidak dapat dihindarkan dalam penelitian ini karena realitas yang ditemukan dalam teks merupakan hasil interpretasi atau penafsiran penulis. Akan tetapi, subjektivitas tersebut diminimalisasi dengan digunakannya hasil analisis linguistik sebagai bukti. Penelitian dengan metode analisis wacana kritis dianggap semakin berkualitas apabila penelitian tersebut semakin banyak memperhatikan konteks historis, sosial, budaya, ekonomi, dan politik dari teks yang diteliti. Oleh karena itu, hal yang banyak disorot adalah aspek-aspek tersebut dalam proses analisis teks dalam buku yang dikaji ini.

Adapun metode analisis wacana yang digunakan dalam tulisan ini adalah Model Analisis Van Dijk. Kuntoro (2008: 45) dalam tulisaanya menjelaskan mengenai model analisis wacana yang terdiri dari tiga hal penting yang mempengarui produksi maupun analisis wacana, yakni: ideologi, pengetahuan, dan wacana. Ideologi mempengaruhi produksi wacana. Tidak ada wacana yang benarbenar netral atau steril dari ideologi penutur atau pembuatnya.

Ideologi adalah sistem kepercayaan baik kepercayaan kolektif masyarakat maupun skemata kelompok yang khas, yang tersusun dari berbagai kategori yang mencerminkan identitas, struktur sosial, dan posisi kelompok. Ideologi merupakan basis sikap sosial. Pengetahuan adalah kepercayaan yang dibuktikan dengan benar (dijustifikasi). Kepercayaan menjadi pengetahuan apabila dimiliki oleh kelompok yang bersangkutan. Dalam kondisi tertentu terdapat pengetahuan yang belum menjadi idiologi sekalipun dimiliki secara kolektif oleh suatu kelompok.

Pengetahuan semacam itu dalam analisis wacana disebut common ground. Dalam produksi wacana, struktur pengetahuan akan mempengaruhi dan mengontrol semantik dan perangkat wacana yang lain. Oleh karena pengetahuan tersebut tidak hanya berkaitan dengan penutur, tetapi berkaitan pengetahuan lain yang dimiliki pendengar, pembaca atau partisipan; maka diperlukan suatu model mental yang komplek tentang situasi pengetahuan lain dari peristiwa komunikatif yang disebut konteks.

Oleh Van Dijk, wacana digambarkan memiliki tiga demensi: teks, kognisi sosial, dan konteks sosial. Inti analisis wacana adalah menggabungkan ketiga demensi wacana tersebut ke dalam satu kesatuan. Dalam demensi teks, yang diteliti adalah bagaimana struktur teks dan strategi wacana yang dipakai untuk menegaskan suatu tema tertentu. Pada tingkat kognisi sosial dipelajari proses produksi berita yang melibatkan kognisi individu penulis berita. Aspek ketiga adalah mempelajari bangunan wacana yang berkembang di masyarakat.

Adapun beberapa elemen yang menjadi perhatian Van Dijk dalam menganalisis wacana secara kritis adalah sebagaimana yang akan dijelaskan selanjutnya.

\section{Tematik}

Tema/topik berarti sesuatu yang telah diuraikan atau sesuatu yang telah ditempatkan (Sobur, 2006: 75) atau gambaran umum dari suatu teks. Dapat disebut juga sebagai gagasan inti, ringkasan atau yang utama dari suatu teks. Topik menunjukkan apa yang ingin disampaikan oleh penulis dalam tulisannya. Menurut Van Dijk wacana umumnya dibentuk dalam tata aturan umum. Teks tidak hanya didefinisikan mencerminkan suatu pandangan tertentu atau topik tertentu tetapi suatu pandangan umum yang koheren (koherensi global), yakni bagian-bagian teks jika dirunut saling mendukung satu dengan yang lain mendukung membentuk gambaran topik umum. Topik tersebut akan didukung oleh sub-sub topik. 


\section{Skematik}

Kuntoro (2008: 45) menyebutkan bahwa skema merupakan alur penyajian informasi dalam wacana. Alur tersebut menunjukkan bagian-bagian teks itu disusun dan diurutkan sehingga membentuk suatu kesatuan. Ada bagian yang didahulukan dan ada bagian yang mengikutinya, ada bagian yang disembunyikan. Skema dalam berita secara umum terbagi menjadi dua bagian yakni: 1) summary yang ditandai dua elemen yakni judul dan lead (teras berita / paragraf pertama); dan 2) story yakni isi berita secara keseluruhan.

\section{Semantik}

Yang termasuk dalam elemen semantik adalah: latar, detail, maksud, praanggapan. Latar adalah bagian berita yang dapat mempengaruhi semantik (arti) yang ingin ditampilkan. Latar yang dipilih menentukan ke arah mana pandangan khalayak akan dibawa. Latar umumnya ditampilkan di awal sebelum pendapat wartawan yang sebenarnya muncul dengan maksud mempengaruhi dan memberi kesan bahwa pendapat wartawan sangat beralasan. Detail berkaitan dengan kontrol informasi yang disampaikan penulis, apa penulis menampilkan informasi secara berlebihan yang menguntungkan dirinya atau citra yang baik, atau akan menampilkan informasi dengan jumlah sedikit bila tidak menguntungkan atau tidak mendukung citra baik. Elemen maksud adalah elemen yang menunjukkan apakah informasi disampaikan secara telanjang atau tidak, eksplisit atau tidak. Pranggapan merupakan pernyataan yang digunakan untuk mendukung makna suatu teks, upaya mendukung pendapat dengan menggunakan premis yang dipercaya kebenarannya. Berbeda dengan latar, latar berupaya mendukung pendapat dengan jalan memberikan latar belakang (Kuntoro, 2008: 47-48).

\section{Sintaksis}

Segi sintaksis (Kuntoro, 2008: 48) adalah berhubungan dengan penataan bentuk dan susunan kalimat untuk membangun penggungkapan gagasan, ide yang logis. Bagian kalimat atau kalimat yang satu dijalin dengan bagian atau kalimat yang lain sehingga membentuk kesatuan yang padu. Bentuk kalimat aktif atau pasif sering digunakan untuk menonjolkan objek ataukah pelaku peristiwa atau kejadian, sering digunakan untuk menyembunyikan pelaku peristiwayang diberitakan. Dalam analisis wacana koherensi adalah pertalian atau jalinan antarkata, proposisi atau kalimat. Koherensi digunakan untuk menghubungkan dua buah kalimat atau paragraf sehingga yang berbeda gagasannya menjadi selaras mendukung gagasan utama yang disampaikan. Koherensi dapat ditandai dengan penunjuk hubungan (atau disebut kohesi) dalam kalimat. Penunjuk hubungan itu di antaranya: 1) kata penghubung dan, sebab akibat, meskipun; 2) kata ganti, 3) pemindahan gagasan / transisi; 4) bentuk kalimat: aktif, pasif.

\section{Stilistik}

Segi stilistika adalah gaya yaitu cara yang digunakan penulis atau pembicara untuk menyatakan maksudnya dengan menggunakan gaya bahasa. Gaya bahasa mencakup diksi atau pilihan kata untuk membentuk citra makna tertentu. Melalui pemilihan kata peristiwa yang sama dapat digambarkan dengan kata yang berbeda. Hal itu berkaitan dengan sikap dan pandangan penulis atau pembicara dalam memaparkan suatu informasi atau persoalan tertentu. Dengan demikian melalui penggunaan gaya bahasa dapat diketahui sikap dan pandangan penulis atau pembicara (Kuntoro, 2008: 45).

\section{Retoris}

Retoris merupakan gaya interaksi pembicara/ penulis ketika menyampaikan tulisan atau pembicaraannya, yakni bagaimana pembicara menempatkan/ memposisikan dirinya di depan khalayak, apakah formal atau informal. Bagian ini berkaitan dengan ekspresi untuk menonjolkan atau menghilangkan bagian tertentu dari suatu teks. Bagian retoris ini merupakan bagian untuk menampilkan citra visual, misal mengenai kelompok yang ditonjolkan dan kelompok yang dimarginalkan. Hal yang termasuk ke dalam elemen ini dalah ekspresi, grafis, dan metafora. Grafis adalah bentuk tulisan, apakah penulisan itu huruf kapital atau huruf kecil, ukuran besar atau kecil, cetak miring, tebal atau bergaris bawah, berwarna atau tidak. Bentuk tulisan tersebut digunakan untuk menyatakan bagian yang ditonjolkan atau dipentingkan dan bagian yang tidak dipentingkan atau dimarginalkan (Kuntoro, 2008: 9). 


\begin{tabular}{|c|c|}
\hline \multicolumn{2}{|c|}{ PEMBAHASAN } \\
\hline Judul & $\begin{array}{l}\text { Sejarah Indonesia untuk SMA/MA } \\
\text { Kelas XI Kelomok Wajib }\end{array}$ \\
\hline Penyusun & : Ratna Hapsari dan M. Adil \\
\hline Editor & : Rikard Rachmat Hadiyansyah \\
\hline Editor Ahli & $\begin{array}{l}\text { Dr. Mohamad Iskandar (Dosen } \\
\text { Fakultas Ilmu Budaya, Departemen } \\
\text { Sejarah, Universitas Indonesia) }\end{array}$ \\
\hline Setting & : Departemen Setting Bupel 3 \\
\hline Ilustrator & : Ahmad Taufik \\
\hline Percetakan & : PT. Gelora Angkasa Pratama \\
\hline Penerbit & : Erlangga \\
\hline Tahun terbit & t: 2012 \\
\hline Kurikulum & : Kuriklum 2013 \\
\hline Kelas & : XI kelompok Wajib \\
\hline
\end{tabular}

\section{Analisis Tematik}

Secara garis besar, penulisan bab judul tema yang dikembangkan Hapsari adalah Organisasi Pergerakan Nasional: Sarana Perjuangan Melawan Kolonialisme di Indonesia. Melihat dari judul sub bab yang dituliskan dalam buku teksnya. Hapsari kemungkinann besar memang sengaja memberikan penegasan bahwa bab yang akan dibahas dalam tema ini sepenuhnya adalah mengenai organisasiorganisasi yang ada pada masa pergerakan.

Membedakan dengan tema-tema lainnya bahwa ciri khas perjuangan di masa ini adalah dengan menggunakan organisasi di mana lebih dimotori oleh orang-orang cendikiawan. Berbeda dengan perjuangan sebelum 1908 yang masih bersifat kedaerahan dan dipimpin oleh ratu adil di setiap wilayah dan berupa perjuangan secara fisik.

\section{Analisis Skematik}

Untuk memberi gambaran secara keseluruhan pada pembaca, teks umumnya menampilkan ringkasan berupa intisari informasi yang termuat dalam lead. Di sini Hapsari sebelum sampai kepada pembahasan mengenai materi organisasi masa pergerakan, penulis memberikan 'peta konsep' mengenai bab tema yang akan dibahas. Hal ini memberikan kemudahan pada siswa untuk memahami keseluruhan materi yang akan dibahas.

\section{Analisis Semantik}

Hal yang dapat dianalisis secara semantik adalah sebagai berikut.

"Setelah tahun 1908, perjuangan melawan kolonialisme dimotori kaum terpelajar melalui organisasi-organisasi pergerakan. Sebagian dari mereka ini memang berasal dari golongan bangsawan, namun mereka ini adalah golongan terdidik dan terpelajar" (Hapsari, 2012: 172).

Dari kutipan wacana di atas dapat diartikan bahwa orang yang terpelajar dan terdidik merupakan golongan yang pantas sebagai penggerak organisasi pergerakan. Mengapa demikian? Sudah jelas karena dalam menjalankan sebuah organisasi dibutuhkan pengetahuan dan pendidikan.

Akan tetapi jika dianalisis lebih lanjut, Hapsari memberikan pandangannya dalam menyatakan bahwa orang-orang dari golongan bangsawan memang yang akan menjadi seorang peminpin dan dianggap pantas menduduki jabatan-jabatan penting. Hal ini kelak akan menciptakan sebuah pemakluman atau kesepakatan di antara pandangan masyarakat bahwa golongan dari darah biru lah yang pantas sebagai peminpin. Akibat yang terjadi dari pandangan seperti ini justru akhirnya melahirkan penyakit masyarakat hingga sekarang. Seorang peminpin daerah, dalam jabatan sebagai bupati misalnya, sebagain merupakan orang-orang yang berdarah biru, atau setidaknya memiliki hubungan kekerabatan dengan keturunan tertentu. Dengan begitu, masalah-masalah seperti korupsi, kolusi, dan nepotisme tetap ada dalam kehidupan masyarakat karena politik dinasti kerap dijalankan dalam pemerintahan.

Penulis merasa menumbuhkan kesadaran berorganisasi bagi siswa sedini mungkin melalui materi pembelajaran sejarah dengan tema organisasi pergerakan nasional sebagai hal yang penting. Para siswa harus dapat terlepas dari pandangan bahwa sebagai seorang peminpin harus dari golongan darah biru atau kelas sosial tinggi. Sebaliknya, siswa harus memiliki paradigma bahwa untuk menjadi peminpin dan sukses dalam hidup adalah melalui kekayaan ilmu dan pengetahuan, yang di mana dapat diperoleh dari berorganisasi. Sejatinya, selain manfaat berorganisasi sebagai wahana 
mendapatkan informasi dan pemahaman baru, pentingnya organisasi juga adalah dapat mengikat rasa persatuan karena merasa senasib seperjuangan yang menciptakan persaudaraan dan identias kebangsaan.

Dalam hal ini, peran organisasi sebagai pencipta kesadaran nasional memberi identitas bangsa dapat tercermin dalam bukunya Haspari adalah sebagai berikut.

"Selanjutnya, gerakan pemuda tumbuh dan berkembang secara mandiri di berbagai daerah di Indonesia. Mula-mula dibentuk sebagai sebuah gerakan solidaritas yang bersifat informal, gerakan-gerakan pemuda ini kemudian menjelma menjadi sebuah gerakan politik atau gerakan kebangsaan dengan cita-cita Indonesia yang merdeka dan maju" (Hapsari, 2012: 187).

"Dalam kongresnya di Solo pada tahun 1926, Jong Java dalam anggaran dasarnya secara nyata menyebutkan hendak menghidupkan rasa persatuan seluruh bangsa Indonesia serta kerja sama dengan semua organisasi pemuda dalam rangka membentuk keindonesiaan. Dengan demikian organisasi ini menghapus sifat Jawasentris serta mulai terbuka bekerja sama dengan pemuda-pemuda nonjawa" (Hapsari, 2012: 188).

Dari kutipan di atas bisa dilihat bahwa semangat kesadaran pemuda untuk memiliki cita-cita sebagai sebuah bangsa telah lahir dengan adanya rasa kesatuan dalam berorganisasi. Dengan adanya sebuah organisasi dapat menghilangkan kotak-kotak kedaerahan, dapat menciptakan rasa persaudaraan dan memunculkan identitas sebagai bangsa.

Adapun beberapa faktor yang melahirkan kesadaran sebagai sebuah bangsa, sehingga masyarakat Indonesia berhak untuk memperjuangkannya diantaranya adalah sebagai berikut.

"Presiden Amerika Serikat Woodrow Wilson (1856-1924) pada bulan Januari 1918 mengumumkan 14 butir dasar penyelesaian yang adil untuk mengakhiri Perang Dunia I

(1914-1918). Salah satu butir yang menarik anggota organisasi pergerakan yang tercantum dalam doktrin itu diantaranya adalah hak menentukan nasib sendiri (right of self determination). Semboyan ini menggema ke seluruh dunia termasuk di tanah jajahan sehingga menimbulkan harapan yang besar. Isi dokrtin ini memang memicu terjadinya sikap perlawanan terhadap Belanda. Maka sejalan dengan Doktrin Wilson, sejaktahun 1922 perhimpunan Indonesia (Indonesische Vereeninging) mencantumkan asas perjuangan yaitu self-help (menolong diri sendiri) dan selfreliance (mengandalkan diri sendiri).

Salah satu cuplikan dari asas perjuangan organisasi ini berbunyi sebagai berikut.

...politik meminta-minta akan ditinggalkan dan sebagai politik terhadap pemerintah yang tidak mengindahkan ucapan Wilson akan dijalankan politik nonkooperatif atau bekerja sama dengan pemerintah penjajah. Nasionalisme yang radikal harus dijadikan senjata yang tajam dan ampuh dalam perjuanagan oleh bangsabangsa yang terjajah dengan semboyan 'hak menentukan nasib sendri' dijadikan dasar yang sah untuk tuntutan dengan ditopang oleh tekad yang bulat dan tenaga yang besar dan kuat dan tersusun baik" (Hapsari, 2012: hlm. 192-193).

Hal lain tercermin juga melalui Revolusi Rusia. Kelas sosial rendah seperti organisasi buruh jika menggabungkan kekuatannya dapat menjelma menjadi kekuatan besar, bahkan dapat menggulingkan kekuasaan negara. Betapa menjadi inspirasinya hal tersebut, terutama terkait lahirnya kesadaran berorganisasi bagi masyarakat pribumi untuk melawan penjajahan. Selain itu, setiap tindakan resisten terhadap pemerintah kolonial akan lebih nyata dan terus terjadi tanpa henti.

"Pada bulan Oktober 1917, kaum revolusioner berhaluan komunis di Rusia, yang disebut kaum Bolsheviks, berhasil menggulingkan monarki Rusia yang saat itu diperintah oleh Tsar (Raja) Nicholas II. Revolusi ini dilatarbelakangi masalah ekonomi dan tindakan Tsar Nicholas II yang sewenang-wenang. Manifasto partai Komunis di Rusia mendasarkan bahwa pembebasan negara-negara jajahan hanya dapat HISTORIA: Jurnal Pendidik dan Peneliti Sejarah, p-issn:2620-4789 | e-issn:2615-7993 
dilakukan dengan persatuan kaum buruh" (Hapsari, 2012: 93).

\section{Analisis Stilistik}

Berbagai pemilihan kata yang dimanfaatkan oleh penulis untuk mendukung penulisan Indonesiasentris di antaranya kata yang berkonotasi negatif bagi pihak penjajah. Contohnya: a) Belanda memaksa..., Belanda mendesak...., ditekan oleh pihak Belanda, Belanda menjajah..., Belanda memonopoli...., Belanda menghasut.... Tindakan yang memberikan penegasan dari penulis, bahwa Indonesia adalah sebagai tokoh protagonis dan penjajah adalah tokoh antagonisnya. Sebagai contoh Hapsari menuliskan dalam salah satu sub bab tentang faktor pendorong lahirnya organisasi pergerakan nasional Indonesia dengan faktor internal: "Kondisi sosial, politik, dan ekonomi yang parah akibat penjajahan (kolonialisme)". Dengan isi

"Penindasan, kekejaman, eksploitasi, dan ketidakadilan yang dilakukan oleh pemerintah kolonial terhadap bangsa Indonesia, misalnya, telah menimbulkan kebencian dan ketidakpuasan rakyat, yang kemudian memicu perlawanan terhadap penjajah"(Hapsari, 2012: 176).

Dengan demikian dapat dipastikan dari gaya penulisan penulis yang membenci penjajahan bahwa Hapsari membuat tulisannya bergaya Indonesiasentris.

\section{Analisis Retoris}

Dalam buku Hapsari memang memberikan beberapa penekanan berupa cetakan yang tebal atau miring pada bagian-bagian tertentu. Hal tersebut sebagai kata kunci dan penekanan pada istilah / konsep / peristiwa yang mendukung pada penulisan masa pergerakan, istilah dalam organisasi, dan pandangan Indonesiasentris. Kemudian ia memberikan semacam daftar indeks pada halaman akhir bukunya sebagai catatan kaki. Adapun beberapa kalimat yang bercetak tebal itu di antarnya: kaum terpelajar, organisasi-organisasi pergerakan, satu nasib, moderat, kooperatif, hari kebangkitan nasional, nonpolitik, radikal, kongres, komisi, sumpah pemuda, revolusi, agtasi, identitas bersama, Indonesia menggugat, demokrasi, gebrakan, berparlemen, dan Kongres Rakyat Indonesia.

\section{SIMPULAN}

Penyampaian materi mengenai masa pergerakan, terutama yang berkaitan dengan pentingnya kesadaran berorganisasi bagi siswasiswa, sangatlah penting. Hal demikian karena dengan menyampaikan pentingnya memiliki kesadaran berorganisasi bagi siswa, siswa akan lebih banyak lagi mendapatkan pengetahuan baru, pengalaman baru, dan pemahaman baru. Selain itu, dalam berorganisasi dapat menumbuhkan rasa persatuan dan rasa persaudaraan. Akan lebih bagus jika rasa persatuan dan persaudaraan tersebut melahirkan rasa nasionalisme yang tinggi bagi siswa.

Memberikan contoh yang baik melalui pembelajaran sejarah dapat dengan mengenalkan tokoh-tokoh pergerakan kepada siswa. Hal demikian akan membangun pemahaman mereka tentang realitas sosial yang ada di sekitar mereka. Dengan lahirnya generasi-generasi yang cerdas sebagai mana yang dicontohkan dalam masa pergerakan, hal demikian akan semakin bagus untuk mengimbangi generasi sekarang ini yang cenderung individualis. Walaupun dalam buku teks sejarah telah dijelaskan mengenai pentingnya makna berjuang melalui organisasi pada masa pergerakan, tetapi pembelajaran sejarah bukan hanya tergantung sepenuhnya terhadap buku teks. Sebagai seorang guru yang mengajarkan sejarah pada peserta didiknya, guru harus memiliki pengetahuan dan pemahaman yang luas mengenai materi yang akan diajarkannya. Buku teks hanya sebagai salah satu media pembelajaran saja.

Untuk membangun tema atau makna wacana dalam pembelajaran, makan elemen wacana yang meliputi pemanfaatan judul, pengembangan tema; pengembangan pola urutan, pemanfaatan aspek sintaksis, semantis, serta penggunaan aspek retoris dapat dimanfaatkan.

\section{REFERENSI}

Darmawan, W. (2010). Analisis Historiografis Terhadap Buku-buku Teks Pelajaran Sejarah SMP dan SMA Tahun 1999-2004. Bandung: Tidak diterbitkan.

Fuchran, A. A. (2007). Pengantar Penelitian dalam Pendidikan. Malang: Pustaka Pelajar.

HISTORIA: Jurnal Pendidik dan Peneliti Sejarah, p-issn:2620-4789 | e-issn:2615-7993 
Hapsari, R. (1012). Sejarah Indonesia Untuk SMA/ MA Kelas XI Kelompok Wajib. Jakarta: Erlangga.

Kuntoro. (2008). Analisis Wacana Kritis (Teori Van Dijk Dalam Kajian Teks Media Massa). Leksika Vol.2 (2) hlm. 45-55.
Sitepu, B.P. (2012). Penulisan Buku Teks Pelajaran. Bandung: Remaja Rosdakarya.

Sobur, A. (2006). Analisis Teks Media, Suatu Pengantar untuk Analisis Wacana, Analisis Semiotik, dan Analisis Framing. Bandung: PT Remaja Rosdakarya. 